\title{
KEMAMPUAN BERBICARA ANAK USIA 5-6 TAHUN DI TK X KAMAL
}

\author{
Alfatihaturrohmah \\ Dewi Mayangsari \\ Muhammad Busyro Karim \\ Pendidikan Guru Pendidikan Anak Usia Dini Fakultas Ilmu Pendidikan \\ Universitas Trunojoyo Madura
}

Email: Alfa.alexandria@yahoo.com, mayangsarie@gmail.com, busyrokarim.dz@gmail.com

Received August 2018, Accepted September 2018, Published October 2018

\begin{abstract}
This research has a purpose to describe of the ability to speak children aged 5-6 years in school.This research uses qualitative approach descriptive method. Data analysis is done through three stages: data reduction, display data, and conclusions: drawing / verifying. Subjects in this study 1 girls aged 5-6 years. The results of this study indicate that 1) the characteristics of the ability to speak children aged 5-6 years in X Kindergarten of Kamal ie children are able to participate in the conversation without monopolizing, but the child has not been able to use words related to the sequence of events, not able to use the word tomorrow and yesterday, the child is only able to say 6 to 7 syllables, the child has not been able to answer the question regularly group activities for 10-15 minutes, the child is only able to use sentences 3 to 4 words. The child also has not been able to answer the question "when", the child is more often silent when others ask because the child has problems speaking. 2) There are obstacles that arise in the ability to speak of children is the phonological process constraints.
\end{abstract}

\section{Keywords: Speech Skills, Children Aged 5-6 Years, phonological process}

Abstrak: Penelitian ini bertujuan untuk mengetahui gambaran kemampuan berbicara anak usia 5-6 tahun di sekolah. Penelitian ini menggunakan pendekatan kualitatif metode deskriptif. Analisis data dilakukan melalui tiga tahapan: data reduction, data display, dan conclusions: drawing/verifying. Subjek dalam penelitian ini 1 anak perempuan usia 5-6 tahun. Hasil penelitian ini menunjukkan bahwa 1) karakteristik kemampuan berbicara anak usia 5-6 tahun di TK X Kamal yaitu anak sudah mampu turut serta dalam percakapan tanpa memonopoli, namun anak belum mampu menggunakan kata-kata yang berhubungan dengan urutan kejadian, belum mampu menggunakan kata besok dan kemarin, anak hanya mampu mengucapkan 6 sampai 7 suku kata, anak belum mampu menjawab pertanyaan secara rutin kegiatan kelompok selama 10-15 menit, anak hanya mampu menggunakan kalimat 3 sampai 4 kata. Anak juga belum mampu menjawab pertanyaan "kapan", anak lebih sering diam ketika orang lain bertanya karena anak mengalami kendala berbicara. 2)Terdapat kendala yang muncul pada kemampuan berbicara anak yaitu kendala proses fonologis.

Kata Kunci: Kemampuan Berbicara, Anak Usia 5-6 Tahun, proses fonologis

\section{PENDAHULUAN}

Program pendidikan ke depan harus menjawab dan menghadapi tantangan sehingga sumber daya manusia kita mempunyai keunggulan dan mampu bersaing di bidang ilmu pengetahuan dan teknologi yang dilandasi dengan wawasan lingkungan (Nisa' dan Luthfiyah, 2014:8). Pendidikan anak usia dini merupakan suatu upaya pembinaan yang ditujukan kepada anak sejak lahir sampai dengan usia enam tahun yang dilakukan melalui pemberian rangsangan pendidikan untuk membantu pertumbuhan dan perkembangan jasmani, maupun rohani agar anak memiliki kesiapan dalam memasuki pendidikan lebih lanjut. (Suyadi, 2014: 23).
Taman Kanak-kanak adalah salah satu bentuk satuan pendidikan anak usia dini pada jalur pendidikan formal yang menyelenggarakan program pendidikan bagi anak usia empat tahun sampai enam tahun. (Hapidin;dkk, 2011: 14).

Anak usia dini adalah individu yang sedang mengalami proses pertumbuhan dan perkembangan yang sangat pesat, bahkan dikatakan sebagai lompatan perkembangan. Anak usia dini memiliki rentang usia yang sangat berharga dibanding usia - usia selanjutnya karena perkembangan kecerdasannya sangat luar biasa. Usia tersebut merupakan fase kehidupan yang unik, dan berada pada masa proses perubahan berupa pertumbuhan, perkembangan, pematangan dan 


\section{Dini, Volume 5, Nomor 2, Oktober 2018, hal 101-109}

penyempurnaan, baik pada aspek jasmani maupun rohaninya yang berlangsung seumur hidup, bertahap dan berkesinambungan. (Mulyasa, 2012: 16).

Setiap peserta didik memiliki perbedaan yang unik, mereka memiliki kekuatan, kelemahan, minat dan perhatian yang berbedabeda. Latar belakang keluarga, latar belakang sosial ekonomi dan lingkungan membuat peserta didik berbeda dalam aktivitas, kreatifitas, intelegensi dan kompetensinya. Berdasarkan Permendikbud nomor 137 tahun 2014, ruang lingkup aspek perkembangan pembelajaran di TK yang saling terkait adalah pengembangan moral dan nilai-nilai agama, pengembangan sosial-emosional, pengembangan kemampuan berbahasa, kognitif, fisik/motorik, dan seni. Apabila salah satu dari aspek perkembangan tersebut mendapat masalah, maka tujuan pendidikan di TK tidak tercapai.

Salah satu aspek yang perlu dikembangkan sejak dini adalah kemampuan bahasa. Berbahasa sebagai kegiatan komunikasi dalam setiap aktivitas anak. Oleh karenanya, betapa pentingnya kemampuan berbahasa tersebut dimiliki oleh anak. Menurut Jamaris, perkembangan bahasa anak usia 5-6 tahun sudah dapat mengucapkan lebih dari 2.500 kosakata, lingkup kosakata yang dapat diucapkan anak menyangkut warna, ukuran, bentuk, rasa, bau, keindahan, kecepatan, suhu, perbedaan, perbandingan, jarak, dan permukaan (kasar-halus), anak usia 5-6 tahun sudah dapat berpartisipasi dalam suatu percakapan. Anak sudah dapat mendengarkan orang lain berbicara dan menanggapi pembicaraan tersebut. Percakapan yang dilakukan oleh anak 5-6 tahun telah menyangkut berbagai komentarnya terhadap apa yang dilakukan oleh dirinya sendiri dan orang lain, serta apa yang dilihatnya. (Jamaris, 2015: 116).

Menurut Bromley dalam Dhieni, menyebutkan bahwa Ada 2 aspek kemampuan bahasa yaitu kemampuan berbahasa reseptif (dimengerti, diterima), seperti: menyimak dan membaca, kemudian kemampuan berbahasa ekspresif (dinyatakan/diungkapkan), seperti: berbicara dan menulis. Kemampuan menyimak merupakan kemampuan anak untuk dapat menghayati lingkungan sekitarnya dan mendengar pendapat orang lain dengan indera pendengaran. Kemampuan berbahasa yang berkembang setelah kemampuan mendengar adalah kemampuan berbicara. Ketika mengajak anak berbicara, ia akan menyerap semua kata kata yang diucapkan orang lain. Anak memiliki kemampuan menulis dipengaruhi oleh kemampuan sebelumnya dalam hal ini kemampuan berbicara, sehingga dapat di tuangkan dalam bentuk tulisan. Kemampuan membaca termasuk kegiatan yang kompleks dan melibatkan berbagai keterampilan seperti mengenali huruf dan kata, menghubungkan dengan bunyi, maknanya serta menarik kesimpulan mengenai maksud bacaan. (Dhieni, 2013: 1.14).

Melihat pentingnya perkembangan bahasa pada anak, maka Pemerintah mengerahkan agar para guru dan juga orang tua dapat memotivasi anak, agar anak sejak dini memiliki kemampuan berbahasa yang baik, terutama kemampuan berbicara agar anak dapat mengekspresikan minat dan kemampuannnya sesuai dengan tingkat perkembangan pada usianya. Tetapi pada kenyataan yang ada, tidak semua anak memiliki kemampuan berbicara yang baik. Ada beberapa kendala yang dialami anak dan dikhawatirkan dapat mempengaruhi kehidupan sehari-hari anak, terutama dalam hal berkomunikasi. Kemampuan berbicara merupakan suatu kemampuan untuk berkomunikasi dengan orang lain, dimana pikiran dan perasaan individu dinyatakan dalam bentuk lambang atau simbol seperti lisan, tulisan, isyarat, bilangan, lukisan, maupun mimik yang digunakan untuk mengungkapkan sesuatu kepada orang lain. (Santrock, 2008:67).

Allen dan Marotz mengungkapkan mengenai kemampuan berbicara anak usia 5-6 tahun, menurut mereka anak usia 5-6 tahun sudah mampu dalam beberapa hal yaitu: 1) Menceritakan cerita yang sudah dia kenal ketika melihat gambar pada buku, 2) Menyebutkan kegunaan sesuatu: sendok untuk makan, gelas untuk minum, 3) Menyebutkan empat sampai delapan warna, 4) Mengucapkan kalimat dengan lima sampai tujuh kata atau lebih panjang, 5) Menyebutkan data pribadi, nama anak, tempat tinggal, 6) Menjawab telepon, memanggil orang yang ditelepon, 7) Mengucapkan kalimat-kalimat yang dapat dipahami orang lain, 8) Menggunakan kata "bolehkah saya" dengan tepat, 9) Berbicara tanpa henti seperti orang mengoceh, 10) 
Bercakap-cakap seperti orang dewasa, banyak bertanya, 11) Menggunakan bentuk kata kerja, urutan kata dan struktur kalimat yang tepat, 12) Berbicara sendiri sambil menentukan langkahlangkah yang diperlukan untuk memecahkan masalah, dan 13) Menceritakan lelucon dan teka-teki (Allen dan Marotz, 2010: 151).

Mencermati harapan pendidikan dengan kenyataan yang ada, tampak masih ada kesenjangan antara harapan dan kenyataan yang perlu mendapat perhatian secara seksama. Sehubungan dengan hal di atas, peneliti telah melakukan observasi awal pada 5 Oktober 2016 di TK X Kamal. Dari hasil observasi pada anak, peneliti menemukan 1 anak usia 4,5 tahun dan pada November 2017 anak sudah berusia 5,5 tahun. Anak tersebut hanya diam saja di kelas. Ketika peneliti mendekati anak dan mengajaknya berbicara, anak hanya diam saja tidak menjawab dan ketika jam istirahat, anak menyendiri tidak bermain bersama temantemannya. Kemudian pada saat proses belajar mengajar berlangsung, anak lebih sering diam. Ketika guru bertanya, anak hanya menggeleng dan mengangguk. Terkadang anak mau menjawab, namun pengucapannya kurang jelas. Anak juga jarang mau saat guru meminta anak untuk maju ke depan untuk menyanyi atau memimpin barisan.

Hasil wawancara dengan guru pada TK X Kamal. Peneliti mendapat keterangan bahwa memang anak tersebut pasif saat di kelas, anak hanya diam saja ketika guru bertanya. Selain itu, anak juga tidak mau bernyanyi apabila guru memerintahkanya, terkadang anak mau mengikuti perintah guru bernyanyi dan berdo'a tetapi hanya komat-kamit tidak bersuara, apabila bersuarapun suaranya tidak jelas sehingga guru sulit memahami apa yang diucapkan anak. Sedangkan hasil wawancara pada orang tua anak, peneliti mendapatkan keterangan bahwa anak belum mampu berbicara dengan jelas. Keseharian anak tersebut jarang bergaul dengan teman sebayanya di rumah, jarang berkomunikasi dengan lingkungan sekitar karena lebih sering sendiri di dalam rumah dan kedua orang tua anak sibuk bekerja.

Apabila ditinjau dari karakteristik kemampuan berbicara anak usia 5-6 tahun oleh para pakar, maka kenyataan yang ada sangatlah bertolak belakang dengan kasus yang peneliti temukan di lapangan. Anak usia dini yang seharusnya sudah dapat menjawab pertanyaan dari orang lain, mengajak berbicara kepada orang lain malah justru pendiam. Hal inilah yang membuat peneliti tertarik melakukan penelitian yang berjudul "Kemampuan Berbicara Anak Usia 5-6 tahun di TK X Kamal". Penelitian ini menggunakan pendekatan kualitatif dengan metode deskrptif. Adapun yang menjadi tujuan dari penelitian ini adalah untuk mendeskripsikan bagaimana kemampuan berbicara anak usia 5-6 tahun di TK X Kamal.

Sejak lahir anak menjalani perkembangan secara bertahap. Susanto yang menjelaskan lima aspek perkembangan anak usia dini sebagai berikut: a) Perkembangan fisik, merupakan hal yang menjadi dasar bagi kemajuan perkembangan berikutnya. Ketika fisik berkembang dengan baik kemungkinan anak untuk dapat lebih mengembangkan keterampilan fisiknya, dan eksplorasi lingkungannya dengan tanpa bantuan dari orang lain. b) Perkembangan intelegensi, merupakan suatu fiksi ilmiah untuk mendeskripsikan perilaku individu yang berkaitan dengan kemampuan intelektual. c) Perkembangan bahasa, bahasa yang dimiliki oleh anak adalah bahasa yang telah dimiliki dari hasil pengolahan dan telah berkembang. Anak telah banyak memperoleh masukan dan pengetahuan tentang bahasa ini dari lingkungan, baik lingkungan keluarga, masyarakat, juga lingkungan pergaulan teman sebaya, atau berkembang didalam keluarga atau bahasa ibu. d) Perkembangan sosial, merupakan pencapaian kematangan dalam hubungan sosial. Dapat juga diartikan sebagai proses belajar untuk menyesuaikan diri terhadap norma-norma kelompok, moral dan tradisi, meleburkan diri menjadi satu kesatuan dan saling berkomunikasi, dan bekerja sama. e) Perkembangan moral, moral berasal dari kata Latin mos (moris), yang berarti adat sitiadat, kebiasaan, peraturan/nilai, atau tata cara kehidupan. Adapun moralitas merupakan kemauan untuk menerima dan melakukan peraturan, nilai-nilai dan prinsip moral.(Susanto, 2011: 33).

Salah satu aspek perkembangan anak adalah perkembangan bahasa. Bahasa merupakan penggunaan sistematis dan konvensional suara-suara (atau tanda-tanda atau simbol-simbol tertulis) untuk tujuan 


\section{Dini, Volume 5, Nomor 2, Oktober 2018, hal 101-109}

komunikasi atau ekspresi diri. (Hoff, 2009: 4). Ada beberapa teori perkembangan bahasa daintaranya konsep perkembangan bahasa anak menurut teori nativistik, konsep pandangan behavioris, konsep perkembangan bahasa anak menurut teori kognitif dan konsep perkembangan bahasa anak menurut teori interaksionis. Berdasarkan pendapat tersebut, maka konsep perkembangan bahasa yang digunakan yaitu teori interaksionis, dimana bahasa dipengaruhi oleh faktor genetik dan lingkungan. Peran orang dewasa dalam proses komunikasi juga sangatlah penting untuk mendukung perkembangan bahasa anak. Orang dewasa menjadi pembantu kedua dalam komunikasi sebagai tenaga ahli yang mampu menciptakan kondisi efektif dalam percakapan.

Bromley dalam Dhieni menyebutkan empat aspek bahasa yaitu menyimak, berbicara, membaca, dan menulis. Kemampuan menyimak dan membaca merupakan keterampilan berbahasa reseptif (dimengerti, diterima), sedangkan kemampuan berbicara dan menulis masuk dalam kategori keterampilan berbahasa ekspresif (dinyatakan). (Dhieni 2013: 1.14). Menurut Kamus Besar Bahasa Indonesia (KBBI), kemampuan berasal dari kata mampu yang berarti yang pertama kuasa (bisa, sanggup) melakukan sesuatu dan kedua berada. Kemampuan sendiri memiliki arti kesanggupan; kecakapan; kekuatan. Sedangkan bicara artinya (akal budi; pikiran) dan berbicara artinya berkata; bercakap; berbahasa. Santrock mengemukakan kemampuan berbicara merupakan suatu kemampuan untuk berkomunikasi dengan orang lain, dimana pikiran dan perasaan individu dinyatakan dalam bentuk lambang atau simbol seperti lisan, tulisan, isyarat, bilangan, lukisan, maupun mimik yang digunakan untuk mengungkapkan sesuatu kepada orang lain. (Santrock, 2008: 67).

Menurut Dhieni, ada beberapa karakteristik perkembangan kemampuan berbicara anak usia 5-6 tahun, antara lain: a) Usia 5 tahun: turut serta dalam percakapan tanpa memonopoli, menggunakan kata-kata yang berhubungan dengan urutan kejadian, menggunakan kata besok dan kemarin, menggunakan kalimat yang terdiri dari 5 kata menjawab telepon, menyampaikan pesan sederhana, dapat mengulang kalimat yang terdiri dari dari 9 dan 10 suku kata, menjawab pertanyaan secara rutin selama kegiatan kelompok (10-15 menit). b) Usia 6 tahun: menggunakan kalimat yang terdiri dari 6 kata, menghubungkan pengulangan atau berbagi benda dengan kelompoknya di kelas, menjawab pertanyaan "kapan", mengulangi kalimat yang terdiri dari 10 dan 11 suku kata. (Dhieni, 2013: 1.14).

Dyer mengungkapkan bahwa ada kendala atau masalah yang umum terjadi dalam berbicara anak yaitu: cadel, kendala proses fonologis, penggunaan suara berlebihan dan gagap. (Dyer, 2004: 84). Cadel adalah salah satu kesalahan bicara yang lazim dan dapat digolongkan menjadi dua jenis dasar yaitu cadel sentral (interdental) dan cadel lateral. Cadel sentral terjadi apabila lidah seorang anak menonjol keluar dari antara gigi-gigi depan dan aliran udara diarahkan ke depan dan kebawah menuju tengah lidah. Banyak anak yang mengalami cadel sentral sampai mereka berusia 4,5 tahun, dan banyak juga yang sembuh dengan sendirinya. Sedangkan cadel lateral terjadi apabila udara keluar dari sekitar sisi-sisi lidah, bukannya dari tengah. Jenis cadel ini bukan merupakan bagian dari urutan perkembangan normal dan cenderung tidak menghilang dengan sendirinya.

Dalam proses fonologis, anak-anak menyederhanakan bunyi-bunyi bahasa yang kompleks ketika mempelajari bahasa. Istilah yang tepat untuk penyederhanaan ini adalah proses fonologis. Kendala proses fonologi ini ditandai dengan adanya penggantian bunyibunyi tertentu atau penghilangan pada bunyi tertentu suatu kata yang dicapkan oleh anak antara lain: 1) Anak mengulang suku kata yang sama dua kali. 2) Anak mengganti sebuah bunyi yang disuarakan dengan bunyi yang tidak disuarakan diawal kata. 3)Anak mengganti bunyi yang disuarakan dengan bunyi yang tidak disuarakan di posisi akhir sebuah kata. 4) Anak menghapus konsonan terakhir dalam suatu kata (seperti tas, menjadi ta). 5) Anak mengganti bunyi-bunyi yang dihasilkan bagian belakang mulut (k, g, dan ng) dengan bunyi yang dibuat di depan mulut. 6) Anak mengubah suatu konsonan dalam sebuah kata untuk membuatnya serupa dengan konsonan lain dalam kata tersebut (cat menjadi tat). 7) Anak mengganti bunyi-bunyi tertentu seperti (f, v, s, $\mathrm{z}$, sh, zh, th, h, j, ch) yang sulit diucapkan menjadi bunyi yang mudah diucapkan seperti 
(t, d, k, dan g). 8)Anak mengganti bunyi-bunyi $\mathrm{r}$ dan 1 dengan $\mathrm{w}$ ata $\mathrm{r}$ (seperti ALLAH menjadi Awoh). 9)Anak menghilangkan semua konsonan dalam suatu kelompok, menghapus satu saja, atau mengganti suatu konsonan yang lain dengan yang lebih mudah diucapkan seperti (krayon, menjadi ayon).

Penggunaan suara yang berlebihan. Kondisi ini yaitu dimana anak-anak terlalu banyak mengeluarkan suara yang berlebihan seperti berteriak, mengeram atau menirukan suara sesuatu, bernyani, berbicara tanpa henti yang dapat mengakibatkan parau yang kronis.

Gagap. Gagap adalah suatu kondisi dimana aliran ucapan terputus oleh jeda-jeda yang abnormal (tanpa suara), pengulanganpengulangan, atau perpanjangan-perpanjangan. Hal ini dapat melibatkan gerakan-gerakan wajah dan tubuh yang tidak lazim yang berkaitan dengan upaya untuk berbicara.

\section{METODE PENELITIAN}

Adapun tujuan dari penelitian ini adalah untuk mengamati dan mendeskripsikan bagaimana kemampuan berbicara anak usia 5 6 tahun di sekolah yaitu di TK X Kamal. Penelitian ini dilakukan di TK X Kamal, Kecamatan Kamal, Kabupaten Bangkalan. Waktu observasi awal dimulai pada 5 September 2016 dan penelitian ini dilaksanakan pada bulan bulan Oktober sampai Desember 2017 atau selama 2 bulan. Alasan utama peneliti memilih TK X Kamal sebagai tempat pengambilan data serta pusat wawancara adalah karena peneliti menemukan anak yang mengalami kendala dalam kemampuan berbicaranya, sehingga peneliti tertarik untuk melakukan penelitian tentang kemampuan berbicara anak usia 5-6 tahun di sekolah. Berdasarkan pandangan tersebut, maka latar penelitian yang ditentukan dalam penelitian ini adalah lingkungan sekolah di TK X Kamal.

Metode yang digunakan dalam penelitian ini yaitu metode penelitian kualitatif dengan mengguanakan pendekatan deskriptif. Menurut Dezin dan Lincoln dalam Moleong mengatakan bahwa "penelitian kualitatif adalah penelitian yang menggunakan latar alamiah, dengan maksud menafsirkan fenomena yang terjadi dan dilakukan dengan jalan melibatkan berbagai metode yang ada"(Moeleong, 2014: 5).

Nazir dalam Prastowo mengungkapkan bahwa "metode deskriptif adalah suatu metode yang digunakan untuk meneliti status kelompok manusia, suatu objek, suatu set kondisi, suatu sistem pemikiran, ataupun suatu kelas peristiwa pada masa sekarang". Sedangkan Arikunto dalam Prastowo juga menegaskan bahwa penelitian deskriptif tidak dimaksudkan untuk menguji hipotesis tertentu, tetapi hanya menggambarkan apa adanya tentang suatu variabel, gejala atau keadaan. (Prastowo, 2011: 186). Penelitian ini menggunakan metode deskriptif karena peneliti ingin menggambarkan bagaimana perkembangan berbicara anak usia 5-6 tahun di TK X Kamal.

Sedangkan prosedur penelitian kualitatif terdiri dari beberapa tahap. Menurut Moleong, terdapat tiga tahapan dalam penelitian kulitatif yaitu Tahap pra lapangan, tahap pekerjaan lapangan, dan tahap analisis data (Moeleong, 2014: 127). Penelitian ini menggunakan ketiga tahap tersebut. Tahap pertama yaitu tahap pra lapangan dimana peneliti berkunjung ke tempat penelitian dan menemukan topik yang diteliti, dan peneliti memilih informan yaitu guru kelas, kepala sekolah dan orang tua anak sekaligus mengamati keadaan lapangan. Setelah peneliti memutuskan untuk memilih sekolah tersebut, peneliti kemudian meminta izin kepada informan yaitu pihak sekolah untuk melakukan penelitian. Peneliti juga melakukan penjajakan lapangan kembali untuk memilih informan yang dibutuhkan. Selanjutnya peneliti memberikan surat pengantar dari pihak kampus untuk melakukan penelitian di tempat yang telah terpilih ada anak yang mengalami kendala dalam kemampuan berbicaranya yaitu di TK X Kamal.

Tahap kedua yaitu tahap pekerjaan lapangan. Pada tahap ini peneliti melakukan persiapan observasi dengan menggunakan pedoman lembar observasi dan wawancara untuk mengamati bagaimana kemampuan berbicara anak di TK $X$ Kamal, serta melakukan persiapan wawancara dengan guru kelas, kepala sekolah dan orang tua anak menggunakan catatan pertanyaan yang sudah disediakan. Setelah semua persiapan terpenuhi, peneliti memasuki lapangan dan berperan serta dalam kegiatan pembelajaran untuk mengumpulkan data.

Tahap ketiga yaitu analisis data. Pada tahap ini peneliti menganalisis data yang telah diperoleh dari lapangan, kemudian mengolah data tersebut. Pemilihan data yang peneliti 


\section{Dini, Volume 5, Nomor 2, Oktober 2018, hal 101-109}

ambil di sini yaitu data yang terkumpul dari catatan lapangan observasi dan catatan lapangan wawancara sesuai dengan fokus penelitian yaitu fokus karakteristik kemampuan berbicara anak usia 5-6 tahun dan fokus kendala berbicara anak usia 5-6 tahun. Selanjutnya peneliti melakukan analisis data dan menarik kesimpulan dari data yang telah diperoleh dari subyek dan informan di TX Kamal kemudian menyajikan data dalam bentuk deskripsi.

Penelitian ini menggunakan data primer dan data sekunder. Data primer dalam penelitian ini adalah objek yang diamati secara langsung oleh peneliti yaitu data hasil observasi pada anak yang mengalami kendala dalam kemampuan berbicaranya dan wawancara dengan guru kelas, kepala sekolah serta orang tua anak. Sedangkan data sekunder yang peneliti gunakan pada penelitian ini yaitu dokumentasi berupa hasil catatan lapangan observasi dan catatan lapangan wawancara, juga dilengkapi dengan foto sebagai lampiran tambahan. Sumber data yang dikumpulkan dalam penelitian ini yaitu kata-kata dan tindakan. Kata-kata diperoleh dari narasumber, serta tindakan dari anak yang diteliti. Data yang diperoleh dari kata-kata dan tindakan akan didokumentasikan dalam bentuk catatan lapangan observasi dan catatan lapangan wawancara, juga foto sebagai penunjang kelengkapan.

Teknik pengumpulan data lapangan, dalam penelitian ini menggunakan beberapa teknik antara lain:

a. Teknik observasi. Peneliti menggunakan teknik observasi tersamar dalam penelitian ini, dimana peneliti dalam melakukan pengumpulan data secara tidak terus terang atau tersamar dalam observasi, alasan peneliti menggunakan teknik observasi ini yaitu untuk menghindari kalau suatu data yang dicari merupakan data yang masih dirahasiakan. Kemungkinan kalau dilakukan dengan terus terang, maka peneliti tidak akan diijinkan untuk melakukan observasi. Observasi ini dilakukan di sekolah untuk mengamati bagaimana kemampuan berbicara anak di TK $\mathrm{X}$ Kamal. b. Teknik Wawancara. Peneliti menggunakan teknik wawancara semi terstruktur dalam melakukan penelitian agar lebih fleksibel dan mudah dalam melakukan wawancara. Wawancara semi terstruktur ini bersifat bebas dimana untuk menemukan permasalahan secara lebih terbuka, informan diajak wawancara dengan dimintai pendapat atau ide-idenya. Peneliti melakukan wawancara kepada guru kelas, kepala sekolah dan orang tua anak.

c. Teknik Dokumentasi. Dalam hal ini peneliti menggunakan dokumen berupa hasil catatan lapangan observasi dan catatan lapangan wawancara. Foto juga digunakan sebagai pelengkap lampiran dalam penelitian ini.

Prosedur analisis data dalam penelitian ini menggunakan prosedur analisis data Miles and huberman. Menurut Miles dan Huberman dalam Sugiyono, "aktivitas dalam analisis data kualitatif dilakukan secara interaktif dan berlangsung secara terus menerus sampai tuntas, sehingga datanya sudah jenuh" (Moeleong, 2014: 127). Adapun aktifitas dalam analisis data, yaitu: 1) data reduction (reduksi data), 2) data display (penyajian data), 3) conclussiondrawwing (verifikasi). Langkah awal yang dilakukan peneliti untuk menganalisis data yaitu dengan melakukan reduksi data. Pada tahap ini peneliti memilih dan memilah data-data penting yang sesuai dengan fokus penelitian. Langkah berikutnya yaitu menyajikan data. Penyajian data dilakukan menggunakan tabel dan teks naratif untuk menyusun pola hubungan setiap fokus sehingga data semakin mudah dipahami. Langkah terakhir dalam analisis data ini yaitu penarikan kesimpulan. Peneliti menarik kesimpulan dari data-data yang telah disajikan melalui teks naratif untuk menjawab rumusan masalah bagaimana karakteristik kemampuan berbicara anak usia 5-6 dan bagaimana kendala berbicara anak usia 5-6 tahun di TK X Kamal.

Uji keabsahan data dalam penelitian ini meliputi beberapa uji diantaranya yaitu: uji kredibilitas, uji transferability, uji dependability dan uji confirmability. Pada uji kredibilitas, peneliti menggunakan triangulasi sumber. Peneliti mengambil data melalui beberapa sumber yang berbeda yaitu guru, kepala sekolah dan orang tua murid untuk 
mendapatkan hasil yang valid. Uji transferability juga digunakan peneliti dengan cara membuat laporan secara jelas dan rinci dan dapat dipercaya oleh pembaca. Uji dependability digunakan peneliti yaitu dengan melakukan audit terhadap keseluruhan proses yang dilakukan dosen pembimbing. Penelitian ini juga menggunakan uji confirmability yaitu dengan menguji hasil penelitian yang sudah dilakukan dengan ujian sidang skripsi.

\section{HASIL DAN PEMBAHASAN}

Berdasarkan hasil penelitian diperoleh gambaran bahwa: Anak masih belum memenuhi semua karakteristik kemampuan berbicara anak usia 5-6 tahun. karakteristik kemampuan berbicara anak usia 5-6 tahun yang muncul disini yaitu Turut serta dalam percakapan tanpa memonopoli. Kondisi dimana anak mampu ikut serta dalam percakapan, tidak memonopoli percakapan atau menguasai percakapan. Disini anak menunjukkan bahwa sudah mampu turut serta dalam percakapan di dalam kelas meskipun terkadang harus ditanya terlebih dahulu oleh guru. Anak juga menunjukkan tidak menyela pembicaraan orang lain, anak baru akan bicara saat gilirannya telah tiba.

Menggunakan kata-kata yang berhubungan dengan urutan kejadian. Kondisi dimana anak seharusnya sudah mampu menggunakan kata yang menunjukkan urutan kejadian seperti urutan aktivitasnya di pagi hari sebelum berangkat sekolah yaitu mandi, gosok, gigi, memakai baju, dan lain-lain. Namun disini anak belum mampu menggunakan kata yang menunjukkan urutan kejadian, ketika guru bertanya anak hanya diam, lalu menggelengkan kepala.

Menggunakan kata besok dan kemarin. Usia 5-6 tahun seharusnya anak sudah mampu mengucapkan kata besok dan kemarin, namun disini anak belum mampu melakukan hal tersebut. Pada saat guru meminta anak mengucapkan kata besok dan kemarin anak hanya diam saja.

Dapat mengulang kalimat yang terdiri dari dari 9 dan 10 suku kata. Kalimat yang terdiri dari 9 sampai 10 suku kata contohnya yaitu sa ya ma u ma kan ro ti ba kar. Namun disini anak hanya mampu mengulang 6 sampai 7 suku kata saja. Ketika guru meninta anak untuk mengulang kalimat saya mau roti bakar, anak hanya mampu mengucapkan ta ya au lo ti a kal atau hanya 7 suku kata.

Menjawab pertanyaan secara rutin selama kegiatan kelompok (10-15 menit), Anak belum mampu menjawab pertanyaan secara rutin selama 10 sampai 15 menit. Anak hanya mampu menjawab 2 pertanyaan saja, tidak sampai 5 menit. Menggunakan kalimat yang terdiri dari 6 kata. Anak belum mampu menggunakan kalimat yang terdiri dari 6 kata, hanya mampu menggunakan 2 sampai 3 kata dalam sekali ucap. Namun anak pernah mengucapkan 4 kata dalam sekali ucap dan itu sudah maksimal. Menjawab pertanyaan "kapan", anak belum mampu menjawab pertanyaan kapan. Ketika guru bertanya kapan anak akan mengembalikan rapotnya anak hanya diam saja. Pertanyaan kapan yang lain juga pernah ditanyakan namun anak hanya menggeleng.

Kendala berbicara yang terjadi pada anak usia dini dapat mempengaruhi kemampuan berbicara anak. Kendala atau masalah yang umum terjadi pada kemampuan berbicara anak yaitu cadel, kendala proses fonologis, penggunaan suara berlebihan dan gagap (Dyer 2004: 84). Cadel adalah salah satu kesalahan bicara yang lazim dan dapat digolongkan menjadi dua jenis dasar yaitu cadel sentral (interdental) dan cadel lateral. Cadel sentral terjadi apabila lidah seorang anak menonjol keluar dari antara gigi-gigi depan dan aliran udara diarahkan ke depan dan kebawah menuju tengah lidah. Banyak anak yang mengalami cadel sentral sampai mereka berusia 4,5 tahun, dan banyak juga yang sembuh dengan sendirinya. Sedangkan cadel lateral terjadi apabila udara keluar dari sekitar sisi-sisi lidah, bukannya dari tengah. Jenis cadel ini bukan merupakan bagian dari urutan perkembangan normal dan cenderung tidak menghilang dengan sendirinya. Namun disini anak tidak menunjukkan kendala cadel, lidah anak normal seperti biasanya ketika berbicara.

Kendala proses fonologis. Anak-anak menyederhanakan bunyi-bunyi bahasa yang kompleks ketika mempelajari bahasa. Istilah yang tepat untuk penyederhanaan ini adalah proses fonologis. Kendala proses fonologi ini ditandai dengan adanya penggantian bunyibunyi tertentu atau penghilangan pada bunyibunyi tertentu suatu kata yang dicapkan oleh 


\section{Jurnal PG-PAUD Trunojoyo : Jurnal Pendidikan dan Pembelajaran Anak Usia}

\section{Dini, Volume 5, Nomor 2, Oktober 2018, hal 101-109}

anak antara lain: Anak mengulang suku kata yang sama dua kali, anak menghapus konsonan terakhir dalam suatu kata, mengganti bunyibunyi yang dihasilkan bagian belakang mulut dengan bunyi yang dibuat di depan mulut.

Anak juga mengubah suatu konsonan dalam sebuah kata untuk membuatnya serupa dengan konsonan lain dalam kata tersebut, mengganti bunyi-bunyi tertentu seperti yang sulit diucapkan menjadi bunyi yang mudah diucapkan, mengganti bunyi-bunyi $\mathrm{r}$ dan 1 dengan bunyi $\mathrm{w}$ atau $\mathrm{r}$, menghilangkan dua konsonan atau lebih yang muncul bersamaan dalam satu kata, menghapus satu saja, atau mengganti suatu konsonan yang lain dengan yang lebih mudah diucapkan.

Kendala yang muncul pada anak disini yaitu anak mengganti bunyi-bunyi huruf yang dihasilkan bagian belakang mulut dengan bunyi yang dibuat di depan mulut yaitu huruf ( $\mathrm{g}$ menjadi d, k menjadi t, dan ng menjadi n), anak juga mengubah suatu konsonan dalam sebuah kata untuk membuatnya serupa dengan konsonan lain dalam kata tersebut yaitu huruf $t$ dan c, Anak mengganti bunyi-bunyi huruf tertentu yang sulit diucapkan menjadi bunyi yang mudah diucapkan yaitu (f menjadi $\mathrm{p}, \mathrm{s}$ menjadi $\mathrm{t}, \mathrm{h}$ menjadi a, $\mathrm{j}$ menjadi $\mathrm{d}, \mathrm{z}$ menjadi d), Anak mengganti bunyi-bunyi $r$ dan 1 dengan bunyi $w$ atau $r$ seperti kata ALLAH menjadi awoh, Anak menghilangkan dua atau lebih konsonan yang muncul bersamaan dalam satu kata, menghapus satu saja, atau mengganti suatu konsonan yang lain dengan yang lebih mudah diucapkan yaitu (krayon, menjadi ayon).

Penggunaan suara yang berlebihan. Kondisi ini yaitu dimana anak-anak terlalu banyak mengeluarkan suara yang berlebihan seperti berteriak, mengeram atau menirukan suara sesuatu, bernyani, berbicara tanpa henti yang dapat mengakibatkan parau yang kronis. Kendala ini tidak muncul pada subjek yang diteliti. Anak tidak berteriak ketika berbicara, tidak menggeram dan tidak berbicara tanpa henti, justru anak malah jarang berbicara.

Gagap. Suatu kondisi dimana aliran ucapan terputus oleh jeda-jeda yang abnormal (tanpa suara), pengulangan-pengulangan, atau perpanjangan-perpanjangan kata-kata. Hal ini dapat melibatkan gerakan-gerakan wajah dan tubuh yang tidak lazim yang berkaitan dengan upaya untuk berbicara. Disini anak tidak menunjukkan gejala gagap, ketika berbicara tidak ada pengulangan kata, tidak ada perpanjangan kata dan tidak terputus-putus ketika mengucapkan kata.

\section{SIMPULAN}

Berdasarkan hasil penelitian diperoleh gambaran bahwa anak masih belum memenuhi semua karakteristik kemampuan berbicara anak usia 5-6 tahun. Kemampuan berbicara anak yang muncul disini yaitu anak sudah mampu turut serta dalam percakapan tanpa memonopoli, namun anak belum mampu menggunakan kata-kata yang berhubungan dengan urutan kejadian, anak belum mampu menggunakan kata besok dan kemarin. Selanjutnya anak juga belum mampu mengulang kalimat yang terdiri dari dari 9 dan 10 suku kata, anak belum mampu menjawab pertanyaan secara rutin kegiatan kelompok selama 10-15 menit, anak belum mampu menggunakan kalimat yang terdiri dari 6 kata, anak juga belum mampu menjawab pertanyaan "kapan".

Terdapat kendala pada kemampuan berbicara pada anak yaitu kendala pada proses fonologis. Kendala yang muncul diantaranya adalah anak mengganti bunyi-bunyi huruf yang dihasilkan bagian belakang mulut dengan bunyi yang dibuat di depan mulut, anak mengubah suatu konsonan dalam sebuah kata untuk membuatnya serupa dengan konsonan lain dalam kata tersebut. Selain itu, anak mengganti bunyi-bunyi huruf tertentu yang sulit diucapkan menjadi bunyi yang mudah diucapkan, anak mengganti bunyi-bunyi $\mathrm{r}$ dan 1 dengan bunyi $\mathrm{w}$ atau r, dan anak juga menghilangkan dua atau lebih konsonan yang muncul bersamaan dalam satu kata, menghapus satu saja, atau mengganti suatu konsonan yang lain dengan yang lebih mudah diucapkan.

\section{Saran}

Adapun saran yang dapat diberikan oleh penulis dari hasil penelitian ini adalah: bagi orang tua diharapkan dapat lebih memperhatikan tumbuh kembang anak, menstimulasi perkembangan bahasa anak terutama pada kemampuan berbicaranya, mengetahui kendala berbicara yang dialami anak baik di rumah maupun di sekolah sehingga memudahkan untuk mencari cara menanganinya, juga diharapkan agar orang tua 
membawa anak ke ahli tumbuh kembang anak. Bagi guru, guru hendaknya lebih mendekatkan diri kepada anak, menciptakan suasana kelas yang nyaman sehingga anak dapat lebih semangat bermain sambil belajar, menstimulasi kemampuan berbicara anak dengan mediamedia yang menarik, dan juga melakukan hubungan kerja sama antara guru dan orang tua di rumah dengan baik. Bagi peneliti selanjutnya, penelitian ini jauh dari kata sempurna, oleh karena itu peneliti selanjutnya diharapkan dapat mengkaji lebih dalam lagi permasalahan tentang kemampuan berbicara anak usia dini, seperti faktor yang mempengaruhi kemampuan berbicara anak usia dini, dampak yang terjadi dalam proses belajar mengajar jika ada kendala berbicara pada anak usia dini, dan juga menambahkan jumlah anak yang diteliti agar dapat mengetahui perbedaan kemampuan berbicara anak yang satu dengan yang lain.

\section{DAFTAR RUJUKAN}

Dhieni, N.; dkk. 2013. Metode Pengembangan Bahasa. Tangerang Selatan: Universitas Terbuka.

Dyer, L. 2009. Meningkatkan Kemampuan Bicara Anak. Jakarta: PT Bhuana Ilmu Populer.

Hoff, E. 2009. Language Development, USA: Florida Atlantic University. Edisi keempat.

Jamaris, M. 2015. Kesulitan Belajar Bagi Anak Usia Dini dan Pra Sekolah. Bogor: Penerbit Ghalia Indah Indonesia.

KBBI. 2017. Kemampuan. (Online). https://kbbi.web.id/mampu. diakses pada 18 Oktober 2017.

KBBI. 2017. Berbicara. (Online). https://kbbi.web.id/bicara. diakses pada 18 Oktober 2017.

Moleong, L J. 2014. Metodologi Penelitian Kualitatif Edisi Revisi. Bandung: PT Remaja Rosdakarya.

Mulyasa. 2012. Manajemen Pendidikan Anak Usia Dini. Bandung: Rineka Rosdakarya.

Nisa', T. F. \& Luthfiyah, K. 2014. Media Gambar untuk Meningkatkan Perbendaharaan Kata pada Siswa TK B Bahrul Ulum Lamongan. Jurnal $P G$ PAUD Trunojoyo : Jurnal Pendidikan dan Pembelajaran Anak Usia Dini. Vol. 1, No. 1: 8-13.

Prastowo, A. 2011. Metode Penelitian Kualitatif dalam Perspektif Rancangan Penelitian. Jogjakarta: Ar-Ruzz Media.

Santrock, J. W. 2007. Perkembangan Anak Edisi Kesebelas Jilid 1. Jakarta: Penerbit Erlangga.

Sugiyono. 2013. Metode Penelitian Kuantitatif Kualitatif dan R\&D. Bandung: Alfabeta.

Sunaryanto, M. 2017. Upaya Meningkatkan Kemampuan Berbicara Anak Usia 5-6 Tahun Dengan Media Poster Di Tk Aba Wonotingal Poncosari Srandakan Bantul Yogyakarta. Skripsi Universitas Yogyakarta. (online),(http://eprints.uny.ac.id/22060 /1/skripsi\%20pdf\%20muhammad\%20s unaryanto.pdf, diakses pada 2 Oktober 2017).

Susanto, A. 2011. Perkembangan Anak Usia Dini Pengantar Dalam Berbagai Aspeknya. Jakarta: Kencana Prenamedia Group.

Suyadi. 2014. Teori Pembelajaran Anak Usia Dini Dalam Kajian Neurosains. Bandung: PT Remaja Rosdakarya 